\title{
POTENSI PENANGANAN LIMBAH DAUN KAYU PUTIH SISA PENYULINGAN DI PMKP KRAI-GUNDIH
}

\author{
Novinci Muharyani ${ }^{*}$, Erlangga Abdillah ${ }^{1}$ \\ ${ }^{1}$ Puslitbang Perhutani \\ Jalan Wonosari Batokan Tromol Pos 6, Cepu, Jawa Tengah \\ * Email: novincimuharyani@yahoo.co.id
}

\begin{abstract}
RINGKASAN
Perum Perhutani memiliki kelompok produk barang dan jasa unggulan, diantaranya adalah forest chemical product, salah satunya adalah minyak kayu putih. Proses penyulingan daun kayu putih memberikan rendemen minyak kurang lebih 0,8-1 \% dimana selebihnya adalah berupa limbah biomassa daun kayu putih. Pemanfaatan limbah biomassa ini, hanya sebagian kecil digunakan kembali sebagai bahan bakar proses penyulingan dan selebihnya akan tertumpuk disekitar pabrik. Prospek pengolahan limbah biomassa daun kayu putih ini diantaranya adalah dengan mengelola secara intensif limbah menjadi kompos daun. Proses pembuatan kompos sendiri belum dilakukan oleh Perum Perhutani. Penelitian ini dilakukan dengan tujuan untuk menganalisis prospek penanganan limbah daun kayu putih secara intensif menjadi kompos daun. Berdasarkan penelitian ini diketahui bahwa pengomposan limbah daun kayu putih dapat dilakukan dengan baik dalam waktu 60 hari (lebih singkat dibandingkan dekomposisi secara alami) dan biaya produksi pada skala percobaan adalah Rp. 346,- / kg kompos.
\end{abstract}

Kata kunci: kompos, limbah daun kayu putih, potensi produksi

\section{PERNYATAAN KUNCI}

- Penyulingan daun kayu putih di seluruh PMKP Perum Perhutani rata-rata menggunakan bahan baku daun kayu putih segar sebanyak 48.200 ton per tahun, output minyak kayu putih yang dihasilkan pertahun sekitar 370 ton. Rendeman dalam proses penyulingan daun kayu putih menjadi minyak daun kayu putih sebesar $0.8 \%$, hal ini menjelaskan bahwa 99.2\% produksi lain adalah limbah daun kayu putih sisa hasil penyulingan yang merupakan potensi bahan baku untuk pembuatan kompos.

- Sisa penyulingan daun kayu putih yang menumpuk dan terjadi dalam waktu yang lama tanpa penanganan yang baik akan berdampak pada permasalahan yang serius jika terjadi kebakaran, hal ini perlu penanganan yang intensif.

- Penanganan limbah daun kayu putih (LDKP) dengan pembuatan kompos dipandang sebagai proses yang layak dikembangkan. Dimana, LDKP sebagai bahan baku yang tersedia, serta 
kebutuhan Perum Perhutani yang tinggi terhadap kompos atau pupuk organik dalam pembuatan dan pemeliharaan tanaman yang di kelola.

- Kluster jenis minyak kayu putih terus dikembangkan, dan peluang pasar minyak kayu putih terbuka luas.

\section{REKOMENDASI KEBIJAKAN}

- Perlu adanya sistem atau kebijakan yang komprehensif dalam penanganan biomassa dari proses produksi sumber daya hutan.

- Manajemen perlu memberikan dukungan dalam rangka penerapan zero waste management dalam proses produksi sumber daya hutan.

\section{PENDAHULUAN}

Perum Perhutani merupakan perusahaan yang bergerak di bidang kehutanan khususnya di Pulau Jawa dan Madura, dan mengemban tugas serta wewenang untuk menyelenggarakan kegiatan pengelolaan Sumber Daya Hutan (SDH) dengan memperhatikan aspek produksi/ekonomi, aspek sosial dan aspek lingkungan.

Perum Perhutani memiliki setidaknya 8 (delapan) kelompok produk barang dan jasa unggulan yang terkait dengan pengelolaan hutan, salah satunya adalah Forest Chemical Products dalam kelompok produk barang dan jasa ini Perum Perhutani menghasilkan produk berupa Gondorukem dan Terpentin. Produk tersebut merupakan hasil destilasi getah pinus yang berkualitas tinggi. Forest Chemical Products lain yang diproduksi adalah: kopal, minyak kayu putih, lak, minyak ylang ylang dan sebagainya. Dalam mendukung Forest Chemical Products khususnya produksi minyak kayu putih, Perum Perhutani mendirikan beberapa Pabrik Minyak Kayu Putih (PMKP) di beberapa lokasi yaitu, di Jawa Timur; PMKP Kupang di Mojokerto, PMKP Bagor di Nganjuk, PMKP Semanding di Tuban, PMKP Sruwi di Pasuruan dan PMKP Sukun di Ponorogo. Jawa Tengah; PMKP Krai di Gundih. Jawa Barat; PMPK Jatimunggu di Indramayu.

Penyulingan daun kayu putih di seluruh PMKP Perum Perhutani menghabiskan bahan produksi daun kayu putih segar sebanyak 48.200 ton per tahun, output minyak kayu putih yang dihasilkan per tahun sekitar 370 ton. Proses penyulingan daun kayu putih selain menghasilkan minyak kayu putih juga menghasilkan produk lain berupa daun kayu putih sisa penyulingan. Rendeman dalam proses penyulingan daun kayu putih menjadi minyak daun kayu putih sebesar $0.8 \%$, hal ini menjelaskan bahwa 99.2\% produksi lain adalah daun kayu putih sisa hasil penyulingan. PMKP yang ada diseluruh Perum Perhutani akan menyisisakan daun kayu putih hasil penyulingan sebanyak kurang lebih 47.800 ton pertahun. Pemanfaatan daun kayu putih 
sisa penyulingan sebagian besar digunakan sebagai bahan bakar boiler untuk proses penyulingan daun kayu putih kembali dan sebagian di manfaatkan masyarakat sekitar pabrik untuk kebutuhan sehari hari seperti bahan bakar memasak, pemanfaatan tersebut menghabiskan sekitar 20\% dari daun kayu putih sisa penyulingan, sehingga masih terdapat sekitar 38.250 ton/tahun atau $80 \%$ yang menumpuk di sekitar PMKP di seluruh Perum Perhutani. Sisa penyulingan daun kayu putih yang menumpuk dan terjadi dalam waktu yang lama tanpa penanganan yang baik akan berdampak pada permasalahan yang serius jika terjadi kebakaran. Tumpukan sisa penyulingan daun kayu putih akan selalu bertambah pertahunnya jika tidak segera di kelola untuk kepentingan lain, diantara pemanfaatan tersebut adalah dengan pembuatan kompos. Pemberian hahan organik yang berasal dari sisa tanaman, hewan ataupun sampah kota kedalam tanah harus sudah mengalami proses pelapukan, bahan organik yang sudah mengalami pelapukan ini merupakan kompos. Kamus Webster's New International Dictionary dalam Rodale et al, (1975) mendefinisikan kompos sebagai campuran yang digunakan untuk pemupukan atau perbaikan lahan berupa campuran pupuk yang terdiri dari bahan-bahan seperti gambut, jamur daun, rabuk, kapur yang tertumpuk dan terdekomposisi. Definisi kompos menurut
Djajakirana (2002) adalah campuran pupuk berbahan organik (tanaman atau hewan atau campuran keduanya) yang telah lapuk sebagian dan dapat berisi senyawa-senyawa lain seperti abu, kapur dan bahan kimia lainnya sebagai bahan tambahan.

Melihat kondisi tersebut maka mengkaji potensi untuk penanganan limbah daun kayu putih diperlukan untuk memanfaatkan seluruh bagian dari sumberdaya hutan sebagai bahan baku yang dapat dikembalikan kembali untuk kepentingan pengelolaan hutan.

\section{SITUASI TERKINI}

Pangsa pasar minyak kayu putih dalam 5 tahun ke belakang, menunjukan serapan yang baik dalam artian adalah produksi minyak kayu putih yang dihasilkan oleh Perum Perhutani akan habis terserap oleh pasar. Produksi minyak kayu putih bergantung pada produksi daun kayu putih sebagai bahan bakunya, pada Gambar 1. dapat dilihat kecenderungan produksi daun kayu putih pada 5 tahun ke belakang di Perum Perhutani.

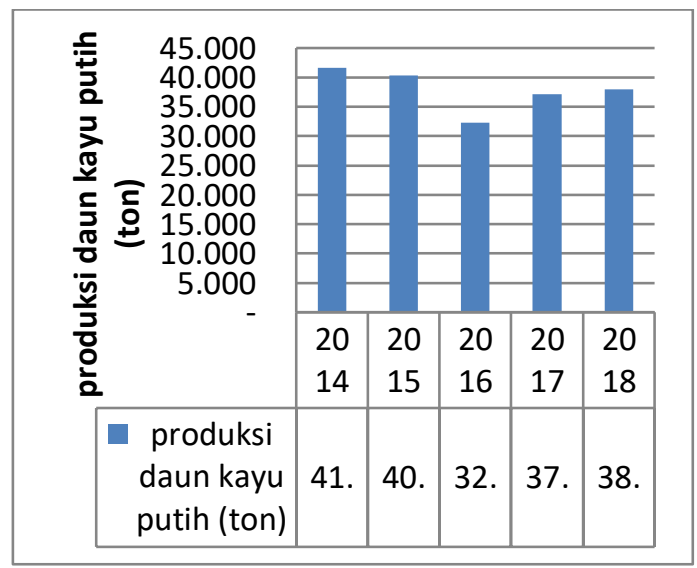

Gambar 1. Grafik produksi daun kayu puth 
Dalam rencana jangka panjang 20192024 yang disusun oleh perusahaan, pengembangan kluster jenis kayu putih diarahkan untuk memenuhi kebutuhan pasar yang masih terbuka. Pengembangan kayu putih dilakukan pada unit manajemen yang terdapat kluster kayu putih namun belum memenuhi skala usaha. Luas hutan produksi kayu putih saat ini adalah seluas 44.239 ha atau 3,18\% dari total luas hutan produksi yang dikelola oleh Perum Perhutani dan pada rencana redesain, luas kawasan akan bertambah menjadi 4,53\% atau menjadi 62.889 ha.

Skala usaha kayu putih diskenariokan sekaligus dengan rencana investasi pabrik minyak kayu putih. Produksi minyak kayu putih dan rencana penambahan investasi pabrik, maka potensi limbah daun kayu putih pun akan mengiringi, sehingga penanganan limbah daun kayu putih yang dihasilkan pun perlu menjadi bagian dari perencanaan proses produksi. Produksi minyak kayu putih pada 5 tahun ke belakang adalah seperti pada Gambar 2.

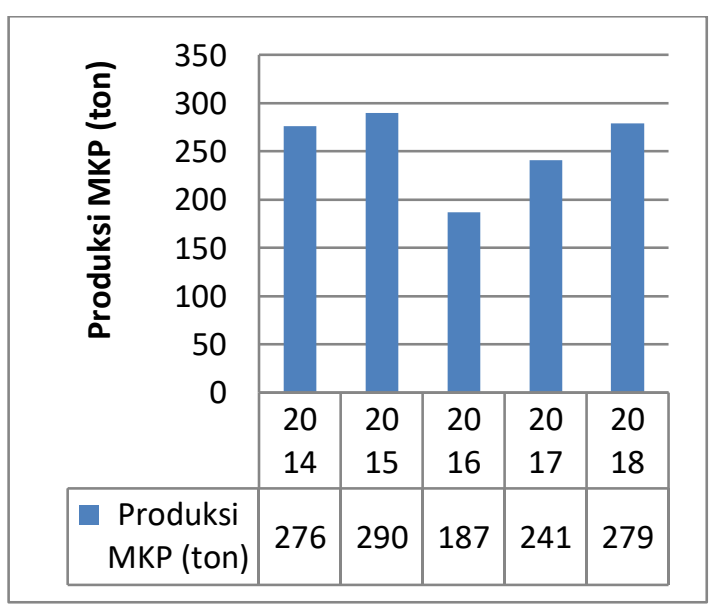

Gambar 2. Grafik produksi minyak kayu putih
Komoditi minyak kayu putih sebagai salah satu forest chemical product yang dihasilkan oleh Perum Perhutani, diharapkan dapat menjadi penyokong pendapatan perusahaan, dimana pada saat ini masih ada gap sebanyak $71 \%$ antara penyediaan dan permintaan produk, sehingga komoditi ini akan terus dikembangkan. Dukungan dari kegiatan penelitian adalah dengan mulai dikembangkannya pertanaman kayu putih dengan menggunakan bibit unggul yang diperoleh dari program pemuliaan serta praktek silvikultur dan pemanenan yang mampu meningkatkan produksi daun kayu putih serta rendemen minyak kayu putih.

\section{METODOLOGI}

Penelitian ini dilaksanakan pada tahun 2016, Contoh LDKP diambil dari PMKP Krai - Gundih Jawa Tengah. Kajian ini menggunakan limbah daun kayu putih (LDKP) segar, yaitu daun dan ranting sisa pengolahan minyak kayu putih yang baru keluar dari ketel pemasakan paling lama 1 bulan yang kemudian disamakan ukurannya secara mekanis. Potensi LDKP ini kemudian diproses dekomposisinya secara anaerob dengan menambahkan dekomposer dengan perbandingan 1 liter dekomposer digunakan untuk 1 ton bahan, sehingga diperoleh pendekatan jumlah dekomposer sebanyak $1 \mathrm{ml}$ untuk $1 \mathrm{~kg}$ bahan. Potensi proses ini kemudian dilihat dari kualitas 
kompos yang dihasilkan dengan standar yang ada.

Potensi penanganan LDKP ini juga melihat dari sisi biaya produksi dengan menghitung komponen biaya tenaga kerja dan biaya bahan tambahan yang diperlukan untuk mendekomposisi bahan limbah daun kayu putih. Keseluruhan biaya kemudian dibebankan kepada jumlah kompos yang dihasilkan. Dari sisi kelayakan bisnis dalam kajian ini di batasi pada ide pembuatan kompos yang dipandang sebagai proses yang layak dikembangkan dari daun kayu putih sisa penyulingan sebagai bahan organik sisa tanaman.

Data yang diperoleh dibahas secara deskriptif dengan mensejajarkan hasil yang diperoleh dengan penelitian sejenis yang sudah dilakukan sebelumnya (deskriptif komparatif).

\section{ANALISIS DAN ALTERNATIF SOLUSI/PENANGANAN}

\section{Potensi penanganan limbah daun kayu putih dengan pembuatan kompos}

Keberhasilan proses dekomposisi bahan organik diantaranya adalah dengan indikator nillai nisbah $\mathrm{C} / \mathrm{N}$. Tamini et al, (2014) dalam Dewani (2015) menyatakan bahwa semakin rendah nisbah $\mathrm{C} / \mathrm{N}(<40)$ pada bahan organik, menunjukkan bahwa bahan organik tersebut telah terdekomposisi oleh mikroba. Nisbah $\mathrm{C} / \mathrm{N}$ LDKP segar pada penelitian ini adalah 19,23\% dan nisbah C/N LDKP yang telah terdekomposisi adalah bervariasi antara 5,86-19,27 \%. Nisbah C/N bahan kompos pada penelitian ini telah mengalami penurunan dari nisbah $\mathrm{C} / \mathrm{N}$ bahan baku segarnya, hal ini dapat diartikan bahwa telah terjadi proses dekomposisi bahan dari bentuk yang kompleks menjadi lebih sederhana.

Nisbah $\mathrm{C} / \mathrm{N}$ pada bahan segar dan kompos matang pada penelitian ini lebih kecil dibandingkan yang dinyatakan oleh Dewani (2015) yaitu 42,52 untuk limbah segar dan 22,53 untuk kompos. Berdasarkan standar SNI (2004) nisbah C/N adalah antara minimal 10 dan maksimal 20, sehingga dari penelitian ini kompos terbaik adalah perlakuan dekomposisi dengan hasil nisbah C/N 14,88 dan 16,52 (tabel 1.)

Tabel 1. Hasil Analisa Nisbah C/N Kompos Limbah Daun Kayu Putih

\begin{tabular}{clccc}
\hline No & Perlakuan & $\begin{array}{c}\text { C-Org } \\
\mathbf{( \% )}\end{array}$ & $\begin{array}{c}\text { N-Total } \\
\mathbf{( \% )}\end{array}$ & $\begin{array}{c}\text { Nisbah C/N } \\
\mathbf{( \% )}\end{array}$ \\
\hline $\mathbf{1}$ & \multicolumn{1}{c}{$\mathbf{2}$} & $\mathbf{3}$ & $\mathbf{4}$ & $\mathbf{5}$ \\
\hline 1 & Daun segar & 51,26 & 2,67 & 19,23 \\
2 & D.0.DSA & 45,38 & 2,35 & 19,27 \\
3 & D.1/4.DSA & 47,60 & 3,20 & 14,88 \\
4 & D.1/2.DSA & 44,52 & 7,59 & 5,86 \\
5 & D.0.TA & 49,04 & 2,65 & 18,48 \\
6 & D.1/4.TA & 47,29 & 2,86 & 16,52 \\
7 & D.1/2.TA & 47,80 & 7,64 & 6,26 \\
\hline
\end{tabular}

Sumber: Hasil analisa dari Departemen Tanah, Fakultas Pertanian UGM 
Dengan metode yang digunakan dalam penelitian ini, dapat diperoleh waktu dekomposisi yang lebih pendek yaitu sekitar 60 hari (2 bulan), dibandingkan dengan dekomposisi secara alami dengan penumpukan selama bertahun-tahun di areal pabrik MKP. Secara alami, dibutuhkan waktu lama untuk mendekomposisi limbah daun kayu dalam tanah (Sutapa dan Aris 2010). Lama waktu dekomposisi dipengaruhi oleh adanya lignoseslulosa pada dinding sel sekunder tanaman (Zumrotiningsih dkk, 2004). Waktu yang diperlukam secara alami adalah 1 tahun, hal ini desebabkan sifat daun yang sangat sulit untuk hancur terdekomposisi, seperti yang diungkapkan oleh Ambarwati (2001) bahwa kandungan zat-zat dalam jaringan seresah mempengaruhi laju dekomposisi.

Secara keseluruhan, reaksi dekomposisi bahan organik dapat ditulis sebagai berikut (Gaur, 1980 dalam Hariyadi, 2003) :

$$
\begin{aligned}
\text { Bahan organik } \longrightarrow & \mathrm{CO} 2 \\
+\mathrm{H} 2 \mathrm{O}+\text { Hara }+ \text { humus }+ \text { Energi } &
\end{aligned}
$$

Aktivitas Mikroorganisme

Penelitian ini menggunakan dekomposer yang mengandung mikroorganisme yang berbeda yaitu dekomposer 1 adalah terdiri atas 3 mikroorganisme utama yaitu Trichoderma sp. Aspergillus sp dan Coriolus sp (kode DSA) dan dekomposer 2 terdiri atas Azotobacter, Lactobacillus, Aspergillus, Streptomyces,
Trichoderma, Saccaromyces dan bakteri antipatogen (kode TA). Menurut Isroi (2008), proses dekomposisi umumnya melibatkan beberapa kelompok organisme baik mikroflora, mikrofauna, makroflora, dan makrofauna. Berdasarkan penelitian Sahwan (2011), proses dekomposisi bahan organik terdapat 3 golongan konsorsium mikroba yang terlibat, diantaranya bakteri, Actinomycetes, dan fungi.

1. Bakteri: Aerobacter, Bacillus megatherium, B. Stearothermophillus, B. Cereus, B. Mycoides, Psedomonas sp., Flavobacterium sp., Micrococcus sp., Sarcina sp., Thiobacillus thiooxidans, $T$. Denitrificans.

2. Actinomycetes: Thermospora viridis, $T$. Curcata, Actinoplanes sp., Micromonospora parva, M. Vulgaris, Pseudonocardia, Streptomyces thermoviolaceus, S. Thermofuscus, Thermonospora fusca.

3. Fungi: Rhizopus nigricans, Rhizoctonia sp., Mucor pusillus, $M$. racemosus, Pennicilium digitatum, Aspergillus flavus, Saccharomyces sp., Pulluloria sp., Hanusenula sp., Trichoderma koningi.

Indikator berjalannya proses dekomposisi bahan organik adalah adanya perubahan suhu selama proses. Suhu optimal dalam proses pengomposan adalah antara 30-45 C (Hariyadi, 2003) sedangkan Sibuea dkk, 1993 dalam Hariyadi (2003) menyatakan bahwa suhu pengomposan dapat meningkat mencapai $65-70 \circ \mathrm{C}$ yang 
terjadi pada awal pengomposan dapat mengurangi nematoda, insekta, jamur dan bakteri patogen.

Pengamatan suhu pada penelitian ini dilakukan setiap hari pada 7 hari pertama proses pengomposan, dan selanjutnya secara berkala pada waktu-waktu tertentu. Peningkatan suhu pada semua perlakuan kecuali pada perlakuan dengan wadah plastik trash bag terjadi pada minggu pertama pengomposan. Suhu pengomposan tertinggi dengan wadah drum, karung dan plastik berturutan $38^{\circ} \mathrm{C}, 36^{\circ} \mathrm{C}$ dan $30^{\circ} \mathrm{C}$. Rentang suhu pengomposan yang terjadi pada minggu pertama pengomposan pada semua perlakuan adalah $29^{\circ} \mathrm{C}-38^{\circ} \mathrm{C}$ sehingga termasuk dalam kriteria mesofilik.

Tabel 2. Perubahan Warna Bahan Kompos Selama Pengomposan

\begin{tabular}{cccccc} 
& & \multicolumn{4}{c}{ Waktu (hari ke-) } \\
\cline { 3 - 6 } No & Perlakuan & \multicolumn{4}{c}{ Warna } \\
\cline { 3 - 5 } & & $\mathbf{1 - 1 0}$ & $\mathbf{2 0}$ & $\mathbf{4 6}$ & $\mathbf{6 0}$ \\
\hline 1 & D.0.DSA & coklat & coklat tua & hitam & hitam \\
2 & D.1/2.DSA & coklat & coklat tua & hitam & hitam \\
3 & D.1/4.DSA & coklat & coklat tua & hitam & hitam \\
4 & D.0.TA & coklat & coklat tua & hitam & hitam \\
5 & D.1/2.TA & coklat & coklat & hitam & hitam \\
6 & D.1/4.TA & coklat & coklat tua & hitam & hitam \\
7 & K.0.DSA & coklat & coklat & hitam & hitam \\
8 & K.1/2.DSA & coklat & coklat & hitam & hitam \\
9 & K.1/4.DSA & coklat & coklat & hitam & hitam \\
10 & K.0.TA & coklat & coklat & hitam & hitam \\
11 & K.1/2.TA & coklat & coklat & hitam & hitam \\
12 & K.1/4.TA & coklat & coklat & hitam & hitam \\
13 & T.0.DSA & coklat & coklat & hitam & hitam \\
14 & T.1/2.DSA & coklat & coklat & hitam & hitam \\
15 & T.1/4.DSA & coklat & coklat tua & hitam & hitam \\
16 & T.0.TA & coklat & coklat & hitam & hitam \\
17 & T.1/2.TA & coklat & coklat & hitam & hitam \\
18 & T.1/4.TA & coklat & coklat & hitam & hitam \\
\hline & & & &
\end{tabular}


Bentuk bahan kompos yang sudah diseragamkan ukurannya menjadikan kompos yang sudah matang tidak mengalami perubahan bentuk yang nyata. Selain itu, kompos matang ditandai dengan struktur yang lebih remah dan tidak berbau. Pada penelitian ini, bau pada bahan kompos mulai tidak tercium pada pengamatan hari ke-46 hingga akhir masa pengomposan, seperti halnya pada pengomposan daun akasia yang didekomposisi selama 6 minggu juga sudah menunjukkan kematangan dengan tidak adanya bau dan struktur menjadi remah (Hariyadi, 2003).

\section{Biaya produksi kompos pada skala kecil}

Bahan baku yang cukup melimpah dan tersedia secara berkelanjutan selama proses penyulingan minyak kayu putih berlangsung, sehingga beban biaya bahan baku dapat dihilangkan. Pada penelitian ini, perhitungan biaya baru pada biaya teknis yang dikeluarkan untuk proses dekomposisi LDKP. Pembuatan kompos dari deposit daun kayu putih cukup menjanjikan dari segi kuantitas maupun kualitas.

Kuantitas dalam hal ini adalah bahan baku kompos tersedia cukup sepanjang tahun. Potensi bahan baku kompos dari deposit pengolahan daun kayu putih dapat dilihat dari jumlah daun kayu putih yang dipanen sepanjang tahun 2010 hingga 2014 yaitu sebanyak 197.155 ton, dengan rendemen $1 \%$ maka akan tersedia bahan baku kompos sebanyak 195.183 ton. Dengan metode yang digunakan dalam penelitian ini, dapat diperoleh waktu dekomposisi yang lebih pendek yaitu sekitar 60 hari (2 bulan), dibandingkan dengan dekomposisi secara alami dengan penumpukan selama bertahun-tahun di areal pabrik MKP. Pembiayaan pembuatan kompos per kilogram kompos jadi untuk kode 0 (nol), $1 / 4$ dan $1 / 2$ berturut-turut adalah Rp. 327,- ; Rp. 346,- dan Rp. 364,-.

Pemanfaatan kompos dari limbah daun kayu putih dapat dimanfaatkan kembali untuk pertanaman kayu putih. Tanaman kayu putih exsisting di Perum Perhutani sampai dengan tahun 2014 adalah 26.126,1 Ha, ditambah dengan penanaman yang telah dilakukan di tahun 2015 dan 2016 berturut-turut seluas 9.282,4 Ha dan 4.230 Ha, maka target tanaman kayu putih yang masih harus dipenuhi menurut Master plan Perhutani adalah seluas 20.420,6 Ha (Anonim, 2015). Dengan asumsi pola tanam plong-plongan, maka kebutuhan pupuk dasar yang dapat disubtitusi dengan kompos asal limbah daun kayu putih adalah seperti pada Tabel 3. 
Tabel 3. Kompos Limbah Daun Kayu Putih sebagai Pupuk Dasar Tanaman Kayu Putih

\begin{tabular}{|c|c|c|c|c|}
\hline No & $\begin{array}{c}\text { Luas Rencana } \\
\text { Tanaman (Ha) }\end{array}$ & N/Ha & $\begin{array}{c}\text { Kebutuhan Pupuk } \\
\text { Dasar } \\
\text { (Kg/lubang tanam) }\end{array}$ & $\begin{array}{c}\text { Jumlah Kompos sebagai } \\
\text { Pupuk Dasar (Ton) }\end{array}$ \\
\hline 1 & $20.420,6$ & 2.000 & 3 & $122.523,6$ \\
\hline
\end{tabular}

Pemanfaatan limbah daun kayu putih menjadi kompos memberikan potensi dalam penyediaan kompos, serta berpeluang untuk menjadikan industri di Perhutani sebagai industri dengan pengeluaran limbah yang minimal atau

\section{REFERENSI}

Ambarwati. 2001. Biodegradasi Limbah Padat Teh oleh Kultur Mikrobia dari Berbagai Sumber. Skripsi. Fakultas Biologi. Universitas Gadjah Mada. Yogyakarta

Anonim. 2015. Master Plan. Direktorat PSDH. Perum Perhutani. Jakarta

Anonim. 2015. Statistik Perum Perhutani Tahun 2010-2014. Prum Perhutani Kantor Pusat. Jakarta.

Dewani, Z. 2015. Kajian Pemanfaatan Biomassa Daun Kayu Putih dan Bakteri Pereduksi Sulfat Dalam Pengolahan Air Asam Tambang. Tesis. Sekolah Pascasarjana. IPB. Bogor.

Djajakirana, G. 2002. Proses Pembuatan, Pemanfaatan dan Pemasaran Vermikompos untuk Pertanian di Indonesia. Makalah pada seminar "Pemanfaatan Teknologi Aplikatif Pertanian dalam Mencapai Suatu Pertanian berkelanjutan". Bogor 12 Mei 2002.

Hariyadi, N. 2003. Studi Percepatan Dekomposisi Serasah Acacia mangium Wild. Dengan Berbagai Aktivator. Skripsi. Jurusan Manajemen. Fakultas Kehutanan. IPB. Bogor. bahkan menjadi tanpa limbah (zero waste management). Selain itu, peluang bisnis dalam penjualan kompos juga terbuka, mengingat harga kompos kemasan yang dijual dalam sak ukuran berat $5 \mathrm{~kg}$ harganya berkisar antara Rp. 5.000,- hingga Rp. 7.000,-.

Isroi, R. Millati, S. Syamsiah, C. Niklasson, M. N. Cahyanto, Lundquist, K., Taherzadeh, M.J. 2011. Biological Pretreatment of Lignocelluloses with White-rot Fungi and Its Application: A Review. BioResources 6 (4).

Rodale, J.L., Rodale, R., Olds, J., Goldman, M.C., Franz, M., Minnich, J. 1975. The Complete Book of Composting. Rodale Books, Inc. Emmaus. Penna.

Sahwan. 2011. Evaluasi Mikroba Fungsional Pupuk Organike Kompos. http:/ /isjd.pdii.lipi.go.id/jurnal/12 21118796_1411-318X.pdf

SNI. 19-7030-2004. Spesifikasi Kompos dari Sampah Organik Domestik.

Sutapa, J. P dan Aris, N. H. 2010. Pemanfaatan Limbah Daun dan Ranting Penyulingan Minyak Daun Kayu Putib (Melaleuca cajuputi Powell) untuk Pembuatan Arang Aktif. Prosiding Seminar MAPEKI XIV :379-385.

Zumrotiningrum, B. D., Susilowati A., Wiryanto. 2004. Seleksi dan Identifikasi Isolat Cendawan Selulotik dan Lignoselulotik dari Limbah Penyulingan Daun Kayu Putih. Biofarmasi 2 (1): 24-28. 